\title{
GROWTH PROMOTION OF PINEAPPLE 'VITÓRIA' BY HUMIC ACIDS AND Burkholderia spp. DURING ACCLIMATIZATION ${ }^{(1)}$
}

\author{
Lílian Estrela Borges Baldotto ${ }^{(2)}$, Marihus Altoé Baldotto ${ }^{(3)}$, Luciano Pasqualoto \\ Canellas $^{(4)}$, Ricardo Bressan-Smith ${ }^{(5)}$ \& Fábio Lopes Olivares ${ }^{(6)}$
}

\begin{abstract}
SUMMARY
In vitro propagation of pineapple produces uniform and disease-free plantlets, but requires a long period of acclimatization before transplanting to the field. Quicker adaptation to the ex vitro environment and growth acceleration of pineapple plantlets are prerequisites for the production of a greater amount of vigorous, well-rooted planting material. The combination of humic acids and endophytic bacteria could be a useful technological approach to reduce the critical period of acclimatization. The aim of this study was to evaluate the initial performance of tissue-cultured pineapple variety Vitória in response to application of humic acids isolated from vermicompost and plant growth-promoting bacteria (Burkholderia spp.) during greenhouse acclimatization. The basal leaf axils were treated with humic acids while roots were immersed in bacterial medium. Humic acids and bacteria application improved shoot growth (14 and $102 \%$, respectively), compared with the control; the effect of the combined treatment was most pronounced (147 \%). Likewise, humic acids increased root growth by $50 \%$, bacteria by $81 \%$ and the combined treatment by $105 \%$. Inoculation was found to significantly increase the accumulation of $\mathrm{N}(115 \%), P(112 \%)$ and $K(69 \%)$ in pineapple leaves. Pineapple growth was influenced by inoculation with Burkholderia spp., and further improved in combination with humic acids, resulting in higher shoot and root biomass as well as nutrient contents (N $132 \%, \mathrm{P} 131 \%$, K $80 \%)$ than in uninoculated plantlets. The stability and increased consistency of the host plant response to bacterization in the presence of humic substances indicate a promising biotechnological tool to improve growth and adaptation of pineapple plantlets to the ex vitro environment.
\end{abstract}

Index terms: Ananas comosus, plant growth-promoting bacteria, diazotrophic bacteria, humic substances, inoculant, biofertilizer.

\footnotetext{
(1) Part of the Doctoral Thesis of the first author developed at the Universidade Estadual do Norte Fluminense Darcy Ribeiro (UENF). Received for publication in October 2009 and approved in August 2010.

(2) Professor at the Universidade Federal de Viçosa Campus Florestal (UFV Campus Florestal). Rodovia LMG 818 Km 6, CEP 35690000 Florestal (MG). E-mail: liestrelaborges@gmail.com

(3) Professor at UFV Campus Florestal. E-mail: marihus@ufv.br

(4) Professor at Laboratório de Solos, UENF. E-mail: canellas@uenf.br

(5) Professor at Laboratório de Genética e Melhoramento de Plantas, UENF. E-mail: bressan@uenf.br

(6) Professor at Laboratório de Biologia Celular e Tecidual, UENF. E-mail fabioliv@uenf.br
} 


\title{
RESUMO: PROMOÇÃO DO CRESCIMENTO DO ABACAXIZEIRO 'VITÓRIA' POR ÁCIDOS HÚMICOS E Burkholderia spp. DURANTE A ACLIMATIZAÇÃO
}

\begin{abstract}
A propagação in vitro de abacaxizeiro produz mudas uniformes e sadias, mas exige longo periodo de aclimatização antes da transferência para o campo. A adaptação ao ambiente ex vitro seguida da aceleração do crescimento das mudas de abacaxizeiro é um pré-requisito para a produção de maior quantidade de material propagativo vigoroso e enraizado. A combinação de ácidos húmicos e bactérias endofíticas pode ser uma tecnologia útil para reduzir o período crítico de aclimatização. O objetivo deste trabalho foi avaliar o desempenho inicial do abacaxizeiro 'Vitória' propagado por cultura de tecidos em resposta à aplicação de ácidos húmicos isolados de vermicomposto e bactérias promotoras de crescimento de plantas (Burkholderia spp.) durante a aclimatização em casa de vegetação. Os ácidos húmicos foram aplicados nas axilas das folhas basais, enquanto as raizes foram imersas no meio bacteriano. Foram observados incrementos no crescimento da parte aérea com a aplicação de ácidos húmicos (14\%) e bactérias (102\%) quando comparado ao controle, com efeito mais pronunciado no tratamento combinado (147\%). Da mesma forma, o crescimento das raízes aumentou $50 \%$ com ácidos húmicos, $81 \%$ com bactérias e $105 \%$ com o tratamento combinado. A inoculação conjunta aumentou significativamente o acúmulo de $N(115 \%), P(112 \%)$ e K (69\%) nas folhas do abacaxizeiro. O crescimento do abacaxizeiro foi influenciado pela inoculação com Burkholderia spp. reforçada pela associação com ácidos húmicos, que resultou em maior massa da parte aérea e raiz e maior conteúdo de nutrientes (N, 132 \%; $P, 131 \%$; K, $80 \%$ ) quando comparado com mudas não inoculadas. A consistência da resposta da planta hospedeira para bacterização na presença de substâncias húmicas aponta para uma ferramenta biotecnológica promissora para melhorar o crescimento e a adaptação de mudas de abacaxizeiro ao ambiente ex vitro.
\end{abstract}

Termos de Indexação: Ananas comosus, bactérias promotoras de crescimento de plantas, bactérias diazotróficas, substâncias húmicas, inoculante, biofertilizante.

\section{INTRODUCTION}

Pineapple is predominantly propagated vegetatively, from adult plant parts obtained after fruit harvest (d'Eekenbrugge \& Leal, 2003). This method is somewhat limited by the irregular size and low number of pest and disease-free plantlets. In vitro propagation provides larger amounts of healthy and uniform plantlets (Teixeira et al., 2001). However, prior to transplanting to the field, the plantlets need a long adaptation period due to the incomplete morphological development, i.e., the reduced root systems, leaves with thin cuticle and external periclinal walls of epidermal cells and low stomatal density (Barboza et al., 2006). The acclimatization period of pineapples varies from 6 to 8 months in the greenhouse until the plants reach a height of $200-300 \mathrm{~mm}$ - an appropriate size for field transference (Teixeira et al., 2001). This lengthy period is the major limitation of a more widespread use of in vitro pineapple propagation.

Plant growth-promoting bacteria (PGPB) can reduce this time. The application of inoculants or biofertilizers containing PGPB can accelerate growth of pineapple plantlets during acclimatization (Mello et al., 2002; Weber et al., 2003; Baldotto et al., 2010). Increased pineapple dry matter in response to inoculation was reported for Burkholderia cepacia in plantlets of 'Smooth Cayenne' and for Asaia bogorensis in plantlets of 'Cayenne Champac' (Weber et al., 2003). On the other hand, the foliar application of humic acids isolated from vermicompost at $15 \mathrm{mmol} \mathrm{L}^{-1}$ of $\mathrm{C}$ promotes significant growth of shoot and root systems as well as nutrient accumulation in leaves of pineapple 'Vitória' during acclimatization (Baldotto et al., 2009).

Humic acids comprise a set of heterogeneous organic molecules, self-assembled in organic aggregates, stabilized by $\mathrm{H}$ bonding and hydrophobic interactions, present in soil, water, sediments, and organic residues (Piccolo, 2002). It was previously observed that humic acids can act as plant growth promoters, particularly in the root system (Façanha et al., 2002; Zandonadi et al., 2007) and nutrient uptake (Chen et al., 2004). Recently, Marques Júnior et al (2008) evaluated the use of PGPB (Herbaspirillum seropedicae) and humic acids on heat-treated sugar cane and observed significant plant growth.

The pineapple variety 'Vitória', released in 2006, has promising characteristics in terms of producer and consumer acceptance, with fusariosis resistance, thornless leaves, cylindrical fruits with yellowish rind, white pulp with high sugar content and good tillering (INCAPER, 2006). However, similarly to other pineapple varieties, the growth of this cultivar during 
acclimatization is slow. The use of combined applications of humic acids and PGPB could be a viable strategy to increase biomass and improve acclimatization of in vitro-propagated pineapple plantlets.

The aim of this study was to evaluate plant growth and nutrient accumulation of pineapple variety 'Vitória' propagated in vitro in response to humic acid application isolated from vermicompost and plant growth-promoting bacteria (Burkholderia spp.) during acclimatization.

\section{MATERIALS AND METHODS}

\section{Plant material}

Pineapple plantlets (Ananas comosus L. Merrill) 'Vitória' (INCAPER, 2006) were provided by the Laboratório de Biotecnologia - BIOMUDAS. The plantlets were propagated in vitro in glass (baby food) pots and kept in MS medium as described by Murashige \& Skoog (1962), without addition of growth regulators and vitamins. The in vitro plantlets were kept in a room with a $25 \mu \mathrm{mol} \mathrm{m} \mathrm{m}^{-2} \mathrm{~s}^{-1}$ flow of photosynthetic photons at $25 \pm 2^{\circ} \mathrm{C}$ and a photoperiod of $16 \mathrm{~h}$. After three months of cultivation, the plantlets were transferred to new MS medium in test tubes. For the following experimental stages, plantlets with approximately $1.5 \mathrm{~g}$ fresh matter were selected.

\section{Bacterial growth and inoculation}

Diazotrophic bacteria of the Laboratório de Biologia Celular e Tecidual, Universidade Estadual do Norte Fluminense Darcy Ribeiro were used. Both bacteria Burkholderia sp. UENF 114111 and Burkholderia silvatlantica UENF 117111 can solubilize phosphate in vitro (Baldotto et al., 2008), and were isolated from plants of Ananas comosus (L.) Merrill 'Smooth Cayenne' which came from an area of the Integrated Agroecological Production System, Embrapa Agrobiologia, Rio de Janeiro, Brazil (Santos, 2008).

The bacteria were grown in liquid DYGS medium (Döbereiner et al., 1995) for $24 \mathrm{~h}$, in a rotary shaker at $120 \mathrm{rpm}$ and $30^{\circ} \mathrm{C}$. For bacterial inoculation, the plantlets were removed from the test tubes and washed in sterilized water to remove the cultivation medium. Next, the roots were immersed in $10 \mathrm{~mL}$ of bacterial medium $\left(10^{8}\right.$ cells $\left.\mathrm{mL}^{-1}\right)$ for $30 \mathrm{~min}$. The substrate was infested with the same medium (Mello et al., 2002). In treatments containing humic acid, plantlets were previously placed in baby food glass pots containing $50 \mathrm{~mL}$ of humic acid isolated from vermicompost at a concentration of $15 \mathrm{mmol} \mathrm{L}^{-1}$ of C for $24 \mathrm{~h}$ (Baldotto et al., 2009).

The main characteristics of the humic acid from vermicompost were determined in previous tests
(Baldotto et al., 2007; Busato, 2008) as follows: $485 \mathrm{~g} \mathrm{~kg}^{-1} \mathrm{C}, 25 \mathrm{~g} \mathrm{~kg}^{-1} \mathrm{~N}$, C/N ratio of 19.4, 3,040 and 2,850 $\mathrm{mmol}_{\mathrm{c}} \mathrm{kg}^{-1}$ of carboxylic and phenolic acids, respectively. The control treatment was immersed for $30 \mathrm{~min}$ in autoclaved DYGS medium. Later, pineapple plants were transferred to $1.0 \mathrm{dm}^{3}$ pots containing substrate Plantmax Hortaliças ${ }^{\circledR}$ for an acclimatization period of 90 days in a greenhouse. Every 14 days during acclimatization, all plants were treated with $5 \mathrm{~mL}$ of nutrient solution (Hoagland \& Arnon 1950). The treatments containing humic acids were treated with additional $5 \mathrm{~mL}$ of $\mathrm{AH}\left(15 \mathrm{mmol} \mathrm{L}^{-1}\right.$ of C) applied to the basal leaf axils of the pineapple plants by an automatic pipette.

\section{Growth analysis}

After 90 days of acclimatization, the plants were collected to measure the following variables: root fresh matter (RFM), shoot fresh matter (SFM), root dry matter (RDM) and shoot dry matter (SDM), after drying by forced air ventilation at $60^{\circ} \mathrm{C}$ for seven days. The foliar area (FA) was estimated by the Leaf Area Meter model LI-3100, LI-COR, USA.

\section{Nutritional analysis}

After drying, leaves of the pineapple plants were ground in a Wiley grinder (mesh $60 \mathrm{~cm}^{-2}$ ). Then the powder was sulfuric acid-digested combined with hydrogen peroxide to determine the total contents of N, P, K, Ca, and Mg. For N, the Nessler Method was used and for $\mathrm{P}$ molecular absorption spectrophotometry (colorimetry, at $725 \mathrm{~nm}$ wavelength), after reaction with ascorbic acid and ammonium molybdate. The $\mathrm{K}$ content was determined by flame photometry and the $\mathrm{Mg}$ and $\mathrm{Ca}$ contents by atomic absorption spectrophotometry. All analyses were performed according to the commonly used methods for pineapple (Baldotto et al., 2009). Nitrogen, P, K, Ca, and Mg contents were estimated by multiplying the shoot dry matter and quantity of the considered nutrient.

\section{Bacteria counting}

Bacteria in roots and shoots were counted by the Most Probable Number (MPN) method (Döbereiner et al., 1995). Samples of $1 \mathrm{~g}$ of roots and $1 \mathrm{~g}$ of shoots were ground in $9 \mathrm{~mL}$ of saline solution $\left(\mathrm{NaCl}, 8.5 \mathrm{~g} \mathrm{~L}^{-1}\right)$ and these dilutions $\left(10^{-1}\right)$ were serially diluted, by diluting $1 \mathrm{~mL}$ of the original dilution in $9 \mathrm{~mL}$ of saline solution and repeating this procedure until the $10^{-7}$ dilution. Aliquots of $100 \mu \mathrm{L}$ of the dilutions were transferred to glass bottles containing $5 \mathrm{~mL}$ of JMV medium (Döbereiner et al., 1995). The bottles were incubated for 7 days at $30^{\circ} \mathrm{C}$. After this period, the bacterial growth was evaluated by the presence of a white film on the medium surface. The number of bacteria was obtained by consulting the McCrady Table with three replications per dilution. 


\section{Experimental design}

An orthogonal experimental design $[(2+2+1)+1]$, with five replications was used to investigate the effects of the Burkholderia sp. UENF 114111 (B1), Burkholderia silvatlantica UENF 117111 (B2), bacteria and humic acid from vermicompost, Burkholderia sp. UENF $114111+\mathrm{HA}$ (B1+HA) and Burkholderia silvatlantica UENF $117111+$ HA (B2+HA), humic acid from vermicompost (HA), and control (-) without application of humic acid and bacteria. The experiment had a randomized complete block design and each experimental unit consisted of one pineapple plant per pot.

\section{Statistical analysis}

The results were submitted to variance analysis and partitioned using mean contrasts (Table 1) according to Alvarez V. \& Alvarez (2006). Then the data were analyzed by the $\mathrm{F}$ test (10, 5 and $1 \%)$.

\section{RESULTS}

It was possible to observe differences in pineapple plantlet growth during the acclimatization period due to inoculation with plant growth-promoting bacteria combined or not with humic acids (Table 2). The advantages of bacteria inoculation on plant growth and nutrient content were quantified using the orthogonal experimental design (control vs. B, Table 3). In fact, the leaf area increased $52.03 \mathrm{~cm}^{2}$ compared to the control, a relative increment of $97 \%$ (Table 3). Inoculation with Burkholderia increased both fresh and dry matter of the root and shoot system, resulting in 115,112 and $69 \%$ higher $\mathrm{N}, \mathrm{P}$ and $\mathrm{K}$ contents than of the control, respectively (Table 3).
Table 1. Contrast coefficients for the treatments: control, humic acid, bacteria, bacteria and humic acid

\begin{tabular}{lrrrrr}
\hline & \multicolumn{5}{c}{ Contrast $^{(2)}$} \\
\cline { 2 - 6 } Treatment $^{(1)}$ & $\mathbf{C}_{1}$ & $\mathbf{C}_{2}$ & $\mathbf{C}_{3}$ & $\mathbf{C}_{4}$ & $\mathbf{C}_{5}$ \\
\hline (-) & -1 & -2 & -2 & 0 & 0 \\
HA & +1 & 0 & 0 & -2 & 0 \\
B1 & 0 & +1 & 0 & 0 & -1 \\
B2 & 0 & +1 & 0 & 0 & -1 \\
B1+HA & 0 & 0 & +1 & +1 & +1 \\
B2+HA & 0 & 0 & +1 & +1 & +1 \\
& & & & & \\
\hline
\end{tabular}

(1) Treatment: (-) = control, HA: humic acid, B1: Burkholderia sp. UENF 114111, B2: Burkholderia silvatlantica UENF 117111. ${ }^{(2)}$ Contrast: $\mathrm{C}_{1}$ : control (-) versus humic acid (HA), $\mathrm{C}_{2}$ : control (-) versus bacteria (B1, B2), $\mathrm{C}_{3}$ : control (-) versus bacteria and humic acid (B1+HA, B2+HA), $\mathrm{C}_{4}$ : humic acid (HA) versus bacteria and humic acid $(\mathrm{B} 1+\mathrm{HA}, \mathrm{B} 2+\mathrm{HA}), \mathrm{C}_{5}$ : bacteria $(\mathrm{B} 1, \mathrm{~B} 2)$ versus bacteria and humic acid $(\mathrm{B} 1+\mathrm{HA}, \mathrm{B} 2+\mathrm{HA})$.

The use of Burkholderia combined with HA also enhanced the effect of PGPB inoculation in comparison to the control (control vs. B+HA, Table 3). The leaf area increased $122 \%$, and shoot (147\%) and root (105\%) growth increased with inoculation in the presence of HA, compared to the control (Table 3). Furthermore, increases of 132, 131 and $80 \%$ in the amounts of N, P and $\mathrm{K}$, respectively, were also observed in the treatments with Burkholderia and HA, compared to the control. The effect of HA isolated from vermicompost was additive. In fact, a significant effect of the contrast $\mathrm{B}$ vs. B+HA on pineapple growth was observed, while HA vs. B+HA considerably enhanced growth of shoots (116\%), roots (36\%), leaf area $(111 \%)$ and nutrient accumulation (N $93 \%, \mathrm{P}$ $102 \%$, K $75 \%$ ) (Table 3).

Table 2. Characteristics of shoot and root growth and nutrient accumulation in 'Vitória' pineapple plants in response to the application of humic acid and plant growth-promoting bacteria during acclimatization

\begin{tabular}{|c|c|c|c|c|c|c|c|c|c|c|}
\hline \multirow{3}{*}{ Treatment $^{(1)}$} & \multicolumn{5}{|c|}{ Growth characteristic } & \multirow{2}{*}{\multicolumn{5}{|c|}{$\begin{array}{c}\text { Nutritional characteristic } \\
\text { Nutrient content }^{(4)}\end{array}$}} \\
\hline & \multicolumn{3}{|c|}{ Shoot $^{(2)}$} & \multicolumn{2}{|c|}{$\operatorname{Root}^{(3)}$} & & & & & \\
\hline & SFM & SDM & FA & RFM & RDM & $\mathbf{N}$ & $\mathbf{P}$ & $\mathbf{K}$ & $\mathrm{Ca}$ & Mg \\
\hline & \multicolumn{2}{|c|}{$\ldots \mathrm{g} / \mathrm{plant} \_$} & $\mathrm{cm}^{2}$ & \multicolumn{2}{|c|}{$\ldots \mathrm{g} / \mathrm{plant} \_$} & \multicolumn{5}{|c|}{$-\mathrm{mg} / \mathrm{plant}$} \\
\hline$(-)$ & 3.48 & 0.34 & 53.90 & 0.45 & 0.07 & 3.16 & 1.27 & 22.93 & 3.20 & 1.14 \\
\hline HA & 3.96 & 0.38 & 56.75 & 0.67 & 0.07 & 3.80 & 1.45 & 23.55 & 4.01 & 1.74 \\
\hline B1 & 6.76 & 0.62 & 103.68 & 0.80 & 0.10 & 6.07 & 2.26 & 40.61 & 6.98 & 4.42 \\
\hline B2 & 7.31 & 0.66 & 108.18 & 0.81 & 0.10 & 7.50 & 3.11 & 37.02 & 7.12 & 5.09 \\
\hline $\mathrm{B} 1+\mathrm{HA}$ & 8.40 & 0.76 & 120.52 & 0.91 & 0.11 & 7.96 & 3.18 & 46.64 & 7.96 & 7.04 \\
\hline $\mathrm{B} 2+\mathrm{HA}$ & 8.74 & 0.61 & 119.32 & 0.92 & 0.11 & 6.68 & 2.66 & 35.86 & 6.83 & 5.20 \\
\hline
\end{tabular}

(1) Treatments: (-) = control, HA: humic acid, B1: Burkholderia sp. UENF 114111, B2: Burkholderia silvatlantica UENF 117111. (2) Shoot: SFM: shoot fresh matter, SDM: shoot dry matter, FA: foliar area. (3) Root: RFM: root fresh matter, RDM: root dry matter. ${ }^{(4)}$ Nutrient contents: N, P, K, Ca, Mg: content of nitrogen, phosphorus, potassium, calcium, magnesium, respectively. 
Table 3. Mean contrasts, relative increments, average square of the residue (QMR) and coefficient of variation (CV) for shoot and root fresh and dry matters, and nutrient accumulation in 'Vitória' pineapple plants in response to the application of humic acid and plant growth-promoting bacteria during acclimatization

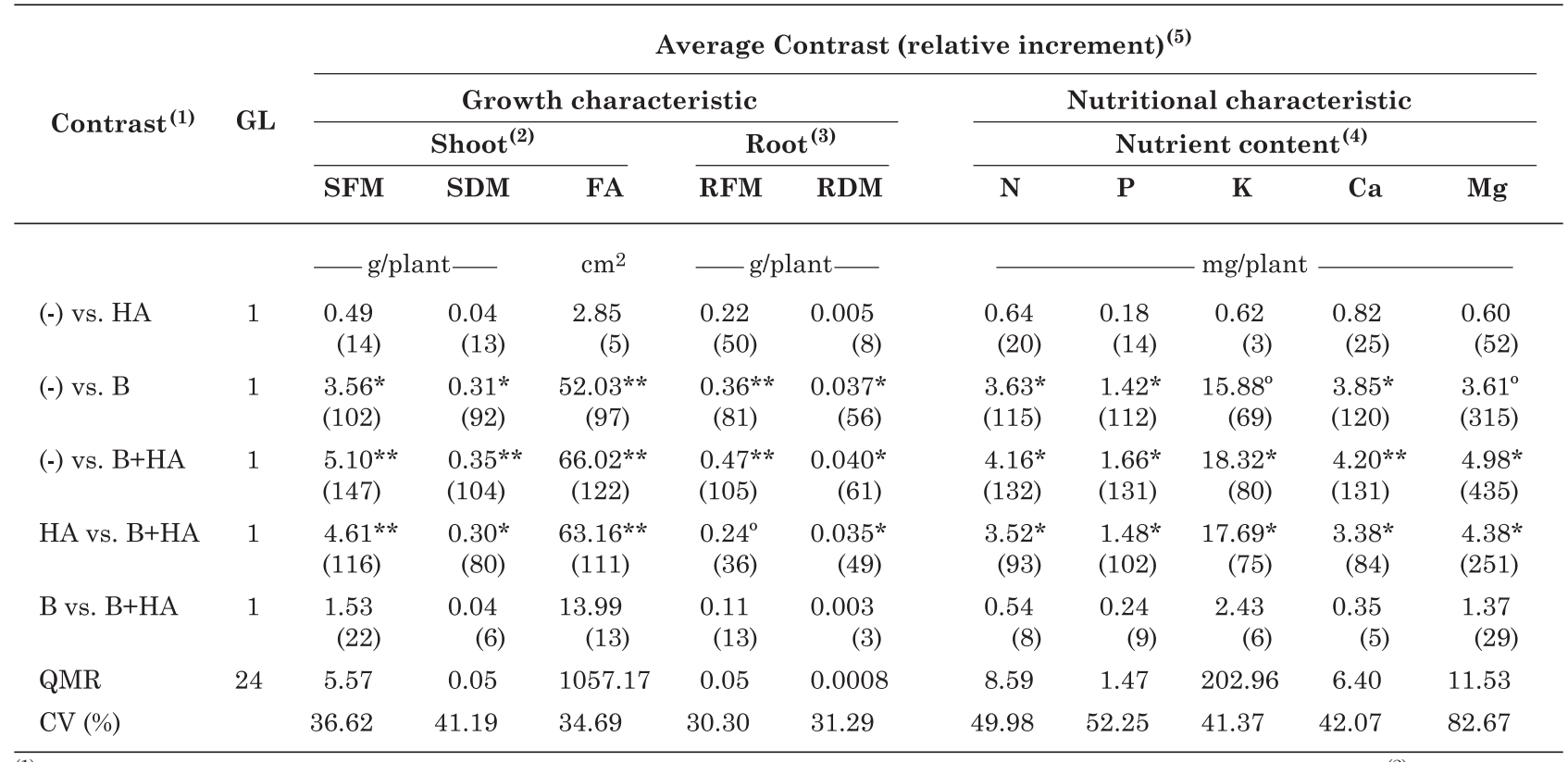

(1) Contrast.: (-) = control, HA: humic acid, B: bacteria (B1, B2), B+HA: bacteria and humic acid (B1+HA, B2+HA). ${ }^{(2)}$ Shoot: SFM: shoot fresh matter, SDM: shoot dry matter, FA: foliar area. ${ }^{(3)}$ Root: RFM: root fresh matter, RDM: root dry matter. ${ }^{(4)}$ Nutrient content: N, P, K, Ca, Mg: nitrogen, phosphorus, potassium, calcium, magnesium content, respectively. ${ }^{(5)}$ Relative increments: $100(\mathrm{x}-\mathrm{y}) / \mathrm{y}$, where $\mathrm{x}$ is the average of the highest value treatment and $\mathrm{y}$ the average of the lowest value treatment. ${ }^{\circ}, *,{ }^{* *}$, significance of 10,5 and $1 \%$ by the $\mathrm{F}$ test, respectively.

The inoculation of pineapple plantlets with endophytic diazotrophic bacteria was effective and increased bacterial population in the shoot and root system by 2 and 3 log units, respectively (Table 4). The HA did not change the most probable number of bacteria in the root system (Table 4).

Table 4. Most Probable Number (log) of endophytic diazotrophic bacteria present in shoot and root of 'Vitória' pineapple plants in response to the application of humic acid and plant growthpromoting bacteria during acclimatization

\begin{tabular}{ccc}
\hline \multirow{2}{*}{ Treatment $^{(1)}$} & \multicolumn{2}{c}{$\begin{array}{c}\text { Most Probable Number (log) of } \\
\text { endophytic diazotrophic bacteria }\end{array}$} \\
\cline { 2 - 3 } & Shoot & Root \\
\hline$\left(^{(-)}\right.$ & $3.60 \pm 0.23$ & $4.38 \pm 0.13$ \\
$\mathrm{HA}^{(2)}$ & $3.10 \pm 0.34$ & $4.55 \pm 0.19$ \\
$\mathrm{~B} 1$ & $5.95 \pm 0.16$ & $7.05 \pm 0.05$ \\
$\mathrm{~B} 2$ & $5.98 \pm 0.00$ & $7.16 \pm 0.07$ \\
$\mathrm{~B} 1+\mathrm{HA}$ & $4.44 \pm 0.43$ & $7.15 \pm 0.00$ \\
$\mathrm{~B} 2+\mathrm{HA}$ & $4.84 \pm 0.09$ & $7.36 \pm 0.31$ \\
\hline
\end{tabular}

(1) Treatment: (-) = control, HA: humic acid, B1: Burkholderia sp. UENF 114111, B2: Burkholderia silvatlantica UENF 117111. ${ }^{(2)}$ Represents the population of endophytic diazotrophic bacteria naturally associated with the host plant.

\section{DISCUSSION}

A biostimulating and biofertilizer effect of Burkholderia (PGPB) in the presence of humic acid (HA) from vermicompost was observed in this study, resulting in growth and nutritional increments of pineapple 'Vitória' plantlets during acclimatization. The period of pineapple acclimatization is critical due to the low growth rate of roots and shoots. In this phase, structural and physiological adjustments of plantlets to ex vitro conditions are crucial for the success in the subsequent phase, i.e., field transplantation (Barboza et al., 2006). Therefore, technologies that promote growth of in vitropropagated pineapple plantlets may have a significant impact on the pineapple production system.

The absence of growth or nutrient accumulation after the 90-day acclimatization period suggests that the response to foliar HA application to promote growth of pineapple plantlets might be a time-related process, since Baldotto et al. (2009) observed differences only after 150 days of acclimatization.

Plant response to a low HA concentration is similar to the activity of auxin-induced cell proton pumps? (Canellas et al., 2002; Zandonadi, 2007). The apoplast acidification loosens cell walls and cells become susceptible to the action of vacuole turgor pressure, 
resulting in cell expansion (Hager et al., 1991). This mechanism is known as acid-growth theory (Rayle \& Cleland, 1992). In addition, the gradient generated by proton pumps contributes to energizing secondary active transport and increasing nutrient uptake (Sze et al., 1999).

Recently, Canellas et al. (2008) verified that organic acid exudation by roots increased in response to HA application. These organic acids may disrupt HA aggregation (Piccolo, 2001) by releasing bioactive molecules previously stabilized by weak ligands, such as auxin units (Façanha et al., 2002). Burkholderia also synthesize and secrete organic acids (Rodríguez $\&$ Fraga, 1999). This fact could partly explain the synergic effect of HA and bacteria on the development of pineapple plantlets.

Inoculation with Burkholderia proved to have a significant effect on pineapple growth and nutrient accumulation compared with the control (Tables 2 and 3). Plant growth promotion in response to Burkholderia inoculation was also observed in the pineapple cultivars 'Pérola' and 'Smooth Cayenne' (Weber et al., 2003). Other plant species such as: tomato, maize (Jiang et al., 2008) and vitis (Ait Barka et al., 2000) also take advantage of the interaction with Burkholderia. The genus Burhholderia includes phytopathogenic bacteria (Burkholder, 1950), endophytic diazotrophic bacteria (Perin et al., 2006) and symbiotic strains of the beta-rhizobia group that induce the formation of nitrogen-fixing root nodules in host plants (Rasolomampianina et al., 2005). The strains used in this study are endophytic diazotrophic and Burkholderia silvatlantica was reported for the first time associated with maize and sugarcane (Perin et al., 2006). In addition to biological nitrogen fixation, some other mechanisms are involved in the PGPB action, e.g., phosphate solubilization (Anandham et al., 2007; Jiang et al., 2008), phytohormone production (Jiang et al., 2008), activation of ACC deaminase (Pandey et al., 2005; Jiang et al., 2008), siderophore synthesis (Jiang et al., 2008) and biocontrol (Cain et al., 2000; Vandamme et al., 2007). The Burkholderia spp. used in this study have the ability to solubilize calcium phosphate $\left(\mathrm{Ca}_{5}\left(\mathrm{PO}_{4}\right)_{3} \mathrm{OH}\right)$ and zinc oxide $(\mathrm{ZnO})$, secrete indol, and act antagonistically in vitro to the phytopathogenic fungus Fusarium subglutinans f. sp. ananas (Baldotto et al., 2010).

Owing to the differences in mechanisms of plant growth stimulation, Burkholderia may potentially be used in the production of inoculants and biofertilizers (Vessey et al., 2003; Anandham et al., 2007), aiming to increase plant growth with a low environmental impact. However, considering the high genomic plasticity and great capacity of adaptation to new environmental conditions of Burkholderia spp, and also that some strains are pathogenic to plants (Burkholder, 1950), animals and humans (Valvano et al., 2006), Compant et al. (2008) emphasized the need for more studies about the risks of dispersion of these bacteria in agricultural environments.
The MPN counts showed that, regardless of HA application, the immersion of the root system efficiently established the endophytic association. Previous studies involving sugar cane and maize (Marques Júnior et al., 2008; Conceição et al., 2008) showed increases from 10 to 100 log units in bacterial populations associated to the host plant. More studies should be carried out in order to evaluate the peculiarities of the combined bacteria-HA application in pineapple by structural and biochemical characterization. As reported by Weber et al. (1999), the low number of bacterial cells found in the noninoculated treatments might be attributed to the presence of natural populations of diazotrophic bacteria associated with pineapple plants.

Although positive responses to application of HA isolated from vermicompost in concentrations from 10 to $80 \mathrm{mg} \mathrm{L}^{-1}$ of $\mathrm{C}$ have been widely documented in literature (Façanha et al., 2002; Quaggiotti et al., 2004; Zandonadi et al., 2007), the magnitude of these responses indicates the need to intensify the studies involving the chemical structure of humic substances and its relation with bioactivity and mechanisms of interaction with plants. In addition, studies explaining the synergic effect of the combined application of HA and endophytic diazotrophic bacteria on plant development are recommended.

The results obtained in this study show the possibility to use the combination of PGPB Burkholderia and bioactive fractions of organic matter in the form of HA in the preparation of biofertilizers and inoculants, which could increase pineapple plantlet adaptation to the ex vitro environment, reducing the acclimatization period. It is a promising alternative that could improve the production of uniform and healthy plantlets.

\section{CONCLUSIONS}

1. Humic acid from vermicompost and diazotrophic bacteria of the genus Burkholderia, separately and even more when combined, promoted the growth of the aerial part, root system and contents of N, P, K, $\mathrm{Ca}$ and $\mathrm{Mg}$ in pineapple plants 'Vitória' cultivated in vitro, in the acclimatization phase.

2. The combined use of humic acid from vermicompost and Burkholderia did not affect the population of endophytic diazotrophic bacteria in the roots of pineapple plantlets.

\section{ACKNOWLEDGEMENTS}

The authors thank the Laboratory Biomudas for the supply of pineapple plantlets; National Council of Scientific and Technological Development (CNPq), 
National Institute of Science and Technology (INCT/ $\mathrm{CNPq}$ ), Carlos Chagas Filho for Research Support of the State of Rio de Janeiro (FAPERJ) for financial support; Dr. Pedro Henrique Monnerat (UENF) and Sr. José Acácio da Silva (UENF) for their help with the nutritional analysis. This research is part of the Doctoral thesis of the first author, who acknowledges the fellowship provided by UENF / FAPERJ.

\section{LITERATURE CITED}

AIT BARKA, E.; BELARBI, A.; HACHET, C.; NOWAK, J. \& AUDRAN, J.C. Enhancement of in vitro growth and resistance to gray mould of Vitis vinifera L. co cultured with plant growth-promoting rhizobacteria. FEMS Microbiol. Lett., 186:91-95, 2000.

ALVAREZ V., V.H. \& ALVAREZ, G.A.M. Comparações de médias ou testes de hipóteses? Contrastes! B. Inf. Soc. Bras. Ci. Solo, 31:24-34, 2006.

ANANDHAM, R.; CHOI, K.H.; GANDHI, P.I.; YIM, W.J.; PARK, S.J.; KIM, K.A.; MADHAIYAN, M. \& SA, T.M. Evaluation of shelf life and rock phosphate solubilization of Burkholderia sp. in nutrient-amended clay, rice bran and rock phosphate-based granular formulation. World J. Microbiol. Biotechnol., 23:1121-1129, 2007.

BALDOTTO, L.E.B.; BALDOTTO, M.A.; OLIVARES, F.L.; VIANA, A.P. \& BRESSAN-SMITH, R. Seleção de bactérias promotoras de crescimento no abacaxizeiro (Ananas comosus L. Merrill) cultivar Vitória durante a aclimatização. R. Bras. Ci. Solo, 34:349-360, 2010.

BALDOTTO, L.E.B.; BALDOTTO, M.A.; GIRO, V.B.; CANELLAS, L.P.; OLIVARES, F.L. \& BRESSAN-SITH, R. Desempenho do abacaxizeiro 'Vitória' em resposta à aplicação de ácidos húmicos durante a aclimatação. R. Bras. Ci. Solo, 33:979-990, 2009

BALDOTTO, L.E.B.; BALDOTTO, M.A.; OLIVARES, F.L. \& BRESSAN-SITH, R. Solubilização de fosfatos por bactérias diazotróficas endofíticas e epifíticas. In: REUNIÃO BRASILEIRA DE FERTILIDADE DO SOLOFERTBIO, 2008, Londrina. Anais. Londrina, Embrapa Soja-IAPAR-UEL/SBCS, 2008. CD-ROM.

BALDOTTO, M.A.; CANELlas, L.P.; CANELA, M.C.; SIMÕES, M.L.; MARTIN-NETO, L.; FONTES, M.P.F. \& VELlOSO, A.C.X. Propriedades redox e grupos funcionais de ácidos húmicos isolados de adubos orgânicos. R. Bras. Ci. Solo, 31:465-475, 2007.

BARBOZA, S.B.S.C.; GRACIANO RIBEIRO, D.; TEIXEIRA, J.B.; PORTES, T.A. \& SOUZA, L.A.C. Anatomia foliar de plantas micropropagadas de abacaxi. Pesq. Agropec. Bras., 41:185-194, 2006.

BURKHOLDER, W.H. Sour skin, a bacterial rot of onion bulbs. Phytopathology, 40:115-117, 1950.

BUSATO, J.G. Química do húmus e fertilidade do solo após adição de adubos orgânicos. Campos dos Goytacazes, Universidade Estadual do Norte Fluminense Darcy Ribeiro, 2008. 135p. (Tese de Doutorado)
CAIN, C.C.; HENRY, A.T.; WALDO, R.H.; CASIDA, L.J. \& FALKINHAM, J.O. Identification and characteristics of a novel Burkholderia strain with broad-spectrum antimicrobial activity. Appl. Environ. Microbiol., 66:41394141, 2000.

CANELLAS, L.P.; FAÇANHA, A.O.; FAÇANHA, A.R. \& OLIVARES, F.L. Humic acids isolated from earthworm induces root mitotic sites and plasma membrane $\mathrm{H}^{+}$. ATPase. Plant Physiol., 30:1951-1957, 2002.

CANELLAS, L.P.; TEIXEIRA JUNIOR, L.R.L.; DOBBSS, L.B.; SILVA, C.A.; MÉDICI, L.O.; ZANDONADI, D.B. \& FAÇANHA, A.R. Humic acids crossinteractions with root and organic acids. Ann. Applied Biol., 153:157-166, 2008.

CHEN, Y.; CLAPP, C.E. \& MAGEN, H. Mechanisms of plant growth stimulation by humic substances: The role of organo-iron complexes. Soil Sci. Plant Nutr., 50:1089-1095, 2004.

COMPANT, S.; NOWAK, J.; COENYE, T.; CLÉMENT, C. \& BARKA, E.A. Diversity and occurrence of Burkholderia spp. in the natural environment. FEMS Microbial Rev., $32: 607-626,2008$

CONCEIÇÃO, P.M.; VIEIRA, H.D.; CANELLAS, L.P.; MARQUES JÚNIOR, R.B. \& OLIVARES, F.L. Recobrimento de sementes de milho com ácidos húmicos e bactérias diazotróficas endofíticas. Pesq. Agropec. Bras., 43:545-548, 2008.

D'EeCKENBRUGGE, G.C. \& LEAL, F. Morphology, anatomy and taxonomy. In: BARTHOLOMEW, D.P.; PAULL, R.E. \& ROHRBACH, K.G., eds. The pineapple: Botany, production and uses. Wallingford, CAB International, 2003. p.13-32.

DÖBEREINER, J.; BALDANI, V.L.D. \& BALDANI, J.I. Como isolar e identificar bactérias diazotróficas de plantas nãoleguminosas. Brasília, Embrapa-SPI, 1995. 60p.

FAÇANHA, A.R.; FAÇANHA, A.L.O.; OLIVARES, F.L.; GURIDI, F.; SANTOS, G.A.; VELLOSO, A.C.X.; RUMJANEK, V.M.; BRASIL, F.; SCHRIPSEMA, J.; BRAZ-FILHO, R.; OLIVEIRA, M.A. \& CANELLAS, L.P. Bioatividade de ácidos húmicos: Efeito sobre o desenvolvimento radicular e sobre a bomba de prótons da membrana plasmática. Pesq. Agropec. Bras., 37:13011310, 2002.

HAGER, A.; DEBUS, G.; EDEL, H.G.; STRANSKY, H. \& SERRANO, R. Auxin induces exocytosis and rapid synthesis of a high-turnover pool of plasma-membrane $\mathrm{H}^{+}$-ATPase. Planta, 185:527-537, 1991.

HOAGLAND, D.R. \& ARNON, D.I. The water culture method of growing plants without soil. Berkeley, University of California, 1950. 32p.

INSTITUTO CAPIXABA DE PESQUISA, ASSISTÊNCIA TÉCNICA E EXTENSÃO RURAL - INCAPER. 'Vitória' nova cultivar de abacaxi resistente a fusariose. Vitória, DCM-Incaper, 2006. (Documento, 148)

JIANG, C.; SHENG, X.; QIAN, M. \& WANG, Q. Isolation and characterization of a heavy metal-resistant Burkholderia sp. from heavy metal-contaminated paddy field soil and its potential in promoting plant growth and heavy metal accumulation in metal-polluted soil. Chemosphere, 72:157-164, 2008. 
MARQUES JUNIOR, R.; CANELLAS, L.P.; SILVA, L.G. \& OLIVARES, F.L. Promoção de enraizamento de microtoletes de cana-de-açúcar pelo uso conjunto de substâncias húmicas e bactérias diazotróficas endofíticas. R. Bras. Ci. Solo, 32:1121-1128, 2008.

MELLO, M.R.F.; MARIANO, R.L.R.; MENEZES, M.; CÂMARA, T.R. \& ASSIS, S.M.P. Seleção de bactérias e métodos de bacterização de crescimento em mudas de abacaxizeiro micropropagadas. Summa Phytopathol., 28:222-228, 2002.

MURASHIGUE, T. \& SKOOG, F. A revised medium for rapid growth and bioassays with tobacco tissue culture. Physiol. Plant., 15:473-497, 1962.

PANDEY, P.; KANG, S.C. \& MAHESHWARI, D.K. Isolation of endophytic plant growth promoting Burkholderia sp. MSSP from root nodules of Mimosa pudica. Curr. Sci., 89:177-180, 2005.

PERIN, L.; MARTINEZ-AGUILAR, L.; PAREDES-VALDEZ, G.; BALDANI, J.I.; ESTRADA-DE LOS SANTOS, P.; REIS, V.M. \& CABALLERO-MELLADO, J. Burkholderia silvatlantica sp. nov., a diazotrophic bacterium associated with sugar cane and maize. Int. J. Syst. Evol. Microbiol., 56:1931-1937, 2006.

PICCOLO, A. The supramolecular structure of humic substances. Soil Sci., 166:810-832, 2001.

QUAGGIOTTI, S.; RUPERT, B.; PIZZEGHELLO, D.; FRANCIOSO, O.; TUGNOLI, V. \& NARDI, S. Effect of low molecular size humic substances on nitrate uptake and expression of genes involved in nitrate transport in maize (Zea mays L.). J. Exper. Bot., 55:803-813, 2004.

RAYLE, D.L. \& CLELAND, R.E. The acid growth theory of auxin-induced cell elongation is alive and well. Plant Physiol., 99:1271-1274, 1992

RASOLOMAMPIANINA, R.; BAILLY, X.; FETIARISON, R.; RABEVOHITRA, R.; B’ENA, G.; RAMAROSEN, L.; RAHERIMANDIMBY, M.; MOULIN, L.; DE LAJUDIE, P.; DREYFUS, B. \& AVARRE, J.C. Nitrogen-fixing nodules from rose wood legume trees (Dalbergia spp.) endemic to Madagascar host seven different genera belonging to á- and â-Proteobacteria. Molec. Ecol., 14:41354146,2005
RODRIGUEZ, H. \& FRAGA, R. Phosphate solubilizing bacteria and their role in plant growth promotion. Biotechnology Advances, 17: 319-339, 1999.

SANTOS, S.T. Biogeografia de bactérias culturáveis associadas às fruteiras tropicais. Campos dos Goytacazes, Universidade Estadual do Norte Fluminense Darcy Ribeiro, 2008. 105p. (Tese de Doutorado)

SZE, H.; LI, X. \& PALMGREN, M.G. Energization of plant membranes by $\mathrm{H}^{+}$-pumping ATPases: Regulation and biosynthesis. Plant Cell, 11:677-689, 1999.

TEIXEIRA, J.B.; CRUZ, A.R.R.; FERREIRA, F.R. \& CABRAL, J.R. Biotecnologia aplicada à produção de mudas: Produção de mudas micropropagadas de abacaxi. Biotecnol. Ci. Desenvol., 3:42-47, 2001.

VALVANO, M.A. Infections by Burkholderia spp.: The psychodramatic life of an opportunistic pathogen. Future Microbiol., 1:145-149, 2006.

VANDAMME, P.; OPELT, K.; KNÖCHEL, N.; BERG, C.; SCHÖNMANN, S.; DE BRANDT, E.; EBERL, L.; FALSEN, E. \& BERG, G. Burkholderia bryophyla sp. nov. and Burkholderia megapolitana sp. nov., mossassociated species with antifungal and plant growth promoting properties. Inter. J. Syst. Evol. Microbiol., 57: 2228-2235, 2007.

VESSEY, K.J. Plant growth promoting rhizobacteria as biofertilizers. Plant Soil, 255:571-586, 2003.

WEBER, O.B.; BALDANI, V.L.D.; TEIXEIRA, K.R.S.; KIRCHHOF, G.; BALDANI, J.I. \& DÖBEREINER, J. Isolation and characterization of diazotrophic bacteria from banana and pineapple plants. Plant Soil, 210:103113, 1999.

WEBER, O.B.; CORREIA, D.; SILVEIRA, M.R.S.; CRISÓSTOMO, L.A.; OLIVEIRA, E.M. \& SÁ, E.G. Efeito da bactéria diazotrófica em mudas micropropagadas de abacaxizeiros Cayenne Champac em diferentes substratos. Pesq. Agropec. Bras., 38:689-696, 2003.

ZANDONADI, D.B.; CANELLAS, L.P. \& FAÇANHA, A.R. Indolacetic and humic acids induce lateral root development through a concerted plasmalemma and tonoplast $\mathrm{H}^{+}$pumps activation. Planta, 225:1583-1595, 2007. 